NBER WORKING PAPER SERIES

POST KEYNESIAN DYNAMIC STOCHASTIC GENERAL EQUILIBRIUM THEORY

\author{
Roger E.A. Farmer \\ Working Paper 23109 \\ http://www.nber.org/papers/w23109 \\ NATIONAL BUREAU OF ECONOMIC RESEARCH \\ 1050 Massachusetts Avenue \\ Cambridge, MA 02138 \\ January 2017
}

This paper was prepared for the 20th annual conference of the FMM Research Network on Macroeconomics and Macroeconomic Policies, "Towards Pluralism in Macroeconomics", held in Berlin on October 20th - 22nd 2016. I am grateful to Torsten Niechoj for inviting me to present a keynote address. Due to unforeseen circumstances, I was unable to attend in person. I thank the organizers, Torsten Niechoj, for nevertheless inviting me to submit a paper for the conference volume. I also thank C. Roxanne Farmer, for editorial assistance. The views expressed herein are those of the author and do not necessarily reflect the views of the National Bureau of Economic Research.

NBER working papers are circulated for discussion and comment purposes. They have not been peer-reviewed or been subject to the review by the NBER Board of Directors that accompanies official NBER publications.

(C) 2017 by Roger E.A. Farmer. All rights reserved. Short sections of text, not to exceed two paragraphs, may be quoted without explicit permission provided that full credit, including $($ ) notice, is given to the source. 
Post Keynesian Dynamic Stochastic General Equilibrium Theory

Roger E.A. Farmer

NBER Working Paper No. 23109

January 2017

JEL No. E0,E12

\begin{abstract}
$\underline{\text { ABSTRACT }}$
This paper explains the connection between ideas developed in my recent books and papers and those of economists who self-identify as Post Keynesians. My own work is both neoclassical and 'old Keynesian'. Much of my published work assumes that people have rational expectations and that 'animal spirits' should be modeled as a new fundamental. I adopt a general equilibrium framework to model the macroeconomy. But although I write from a neo-classical tradition the themes I explore in my published writing have much in common with heterodox economics. This paper explains the common elements between these seemingly disparate traditions. I make the case for unity between Post-Keynesian and General Equilibrium Theory under the banner of PostKeynesian Dynamic Stochastic General Equilibrium Theory.
\end{abstract}

Roger E.A. Farmer

UCLA

Department of Economics

Box 951477

Los Angeles, CA 90095-1477

and NBER

rfarmer@econ.ucla.edu 


\title{
Post Keynesian Dynamic Stochastic General Equilibrium Theory
}

\author{
Roger E. A. Farmer*
}

\section{Abstract}

This paper explains the connection between ideas developed in my recent books and papers and those of economists who self-identify as Post Keynesians. My own work is both neoclassical and 'old Keynesian'. Much of my published work assumes that people have rational expectations and that 'animal spirits' should be modeled as a new fundamental. I adopt a general equilibrium framework to model the macroeconomy. But although I write from a neo-classical tradition the themes I explore in my published writing have much in common with heterodox economics. This paper explains the common elements between these seemingly disparate traditions. I make the case for unity between Post-Keynesian and General Equilibrium Theory under the banner of Post-Keynesian Dynamic Stochastic General Equilibrium Theory.

\section{Introduction}

In writing The General Theory (Keynes, 1936), Keynes changed the course of history. What were the most important ideas in that book and how should we incorporate them into modern approaches to macroeconomics?

One response that can, and has, been offered is: Who cares what a dead economist had to say? We have moved on. At a conference of heterodox macroeconomists, presenting that answer would no doubt be perceived as unsatisfactory. In contrast to some of my fellow neoclassical and New-Keynesian economists, I believe we have a great deal to learn from the history of thought. But my answer to the question: what can we learn from Keynes? is different from both mainstream approaches to Keynes' ideas, and to the views of many of those attending this conference.

* UCLA, University of Warwick and NIESR.

$\psi$ This paper was prepared for the $20^{\text {th }}$ annual conference of the FMM Research Network on Macroeconomics and Macroeconomic Policies, "Towards Pluralism in Macroeconomics", held in Berlin on October $20^{\text {th }}-22^{\text {nd }} 2016$. I am grateful to Torsten Niechoj for inviting me to present a keynote address. Due to unforeseen circumstances, I was unable to attend in person. I thank the organizers, Torsten Niechoj, for nevertheless inviting me to submit a paper for the conference volume. I also thank C. Roxanne Farmer, for editorial assistance. 
I have consistently argued that Keynes made three important points. ${ }^{1}$ First, the views of participants in the stock market are an independent fundamental force that influences, not just the financial markets, but also the real economy. Second, the labor market is not an auction and the unemployment rate can potentially end up in many possible 'equilibrium' states. And third, government has an obligation to do something about this.

Before I am hit with eggs from a torrent of Minsky supporters let me say that I am using the word equilibrium here in the sense of a one period temporary equilibrium that may, or may not, be moving over time. ${ }^{2}$

I hope that I have said very little that will be controversial to this audience. Where I suspect I differ, is that I see a real benefit in a research agenda that reconciles these ideas with Walrasian general equilibrium theory. ${ }^{3}$ And once one accepts that that is a valid enterprise, the best framework with which to reconcile Keynes with Walras, is Dynamic Stochastic General Equilibrium theory. I make the case here for a Post-Keynesian DSGE approach to macroeconomics.

Now, let me be clear, I do not think that the atemporal, Walrasian fiction of complete financial markets is the right approach. There clearly was no grand market meeting at the beginning of time in which we all traded date-, location- and state- specific commodities into the infinite future. A more reasonable starting point, in my view, is the temporary equilibrium framework constructed by Hicks in Value and Capital (Hicks, 1939).

In Hicks' framework, market participants come together in a weekly market meeting to trade commodities. The current week is linked to past weeks through stocks of capital goods and financial assets that the participants bring to market: And it is linked to future weeks by the expectations of market participants about future state-contingent prices and future production opportunities.

If one agrees to follow this paradigm, one must ask how goods are allocated in each weekly meeting. The Walrasian answer is that prices are adjusted by a fictional auctioneer who ensures that, conditional on the state of expectations, the quantities demanded and supplied of every good are equal. Hicks' answer, developed after reading a draft of the General Theory, was that some prices are slow to adjust, and, as a consequence, there may be demand spillovers from one market to another. ${ }^{4}$ This is the Patinkin-Clower-Leijonhufvud (PCL) interpretation of The General Theory. ${ }^{5}$

${ }^{1}$ (Farmer R. E., 2008; 2010a; 2010b; 2012a), (2013).

${ }^{2}$ I refer here to Hyman Minsky (Minsky, 2008) who argued that the economy is never in equilibrium in the sense in which that term is used in the natural sciences; as the rest point of a dynamical system.

3 (Walras, 1899).

${ }^{4}$ See (De Vroey, 2006), who discusses the evolution of Hick's ideas.

${ }^{5}$ (Patinkin, 1956), (Clower, 1967), (Leijonhufvud, 1966). 
The PCL view was taken up and further developed by Benassy and Malinvaud in France and by Barro and Grossman in the United States and, even though markets do not clear in the Walrasian sense, their interpretation of how to construct macroeconomic theory is very much a DSGE approach in the sense in which orthodox macroeconomists use that term. ${ }^{6}$ My point is that the DSGE approach is a very broad church that includes models which a purely Walrasian theorist might refer to as disequilibrium. Equilibrium, like beauty, is in the eye of the beholder.

\section{Who is a Post-Keynesian?}

Who knows? Who cares? I believe that intellectuals are, or should be, inclusive in their acceptance of alternative approaches to interesting questions and I am not going to propose a Keynesian version of the Nicene Creed. If you self-identify as Post-Keynesian; that's good enough for me. I do think, however, that we can draw an interesting analogy with evolutionary biology. In his wonderful book, the Beak of the Finch, Jonathan Weiner (Weiner, 1995) describes evolution in action on the Galapagos Islands.

In response to a prolonged period of drought, Weiner describes how the characteristics of the birds that inhabit different parts of the island begin to diverge. If drought conditions persist, the finches on one part of the island stop breeding with those on another and, slowly, separate species begin to emerge. When eventually, the rains return with the arrival of El Niño, interbreeding recommences and the divergent characteristics of the emergent populations are merged, once more, into a single species.

When did Post-Keynesians stop interbreeding with their orthodox cousins? It was in 1955 . That was the year when Paul Samuelson introduced the neo-classical synthesis into the third edition of his influential introductory textbook. ${ }^{7}$ According to the neo-classical synthesis, the economy is Keynesian in the short-run, when prices and wages are 'sticky', and classical in the long-run when they have time to converge to their Walrasian levels. Participants at this conference do not need me to point out that this idea has very little to do with Keynes.

The intellectual descendent of the neo-classical synthesis is New-Keynesian economics, an approach that is neither new nor Keynesian and that has more in common with Hume's essay, Of Money, (Hume, 1777), than with The General Theory. New-Keynesian economics was constructed on the core of a representative agent real business cycle model by a group of neoclassical economists, notably Michael Woodford in his Magnus opus Interest and Prices (Woodford, 2003). It is built onto the real business cycle framework by adding costs of changing

\footnotetext{
${ }^{6}$ (Benassy, 1975) , (Malinvaud, 1977), (Barro \& Grossman, 1971).

${ }^{7}$ See Kerry Pearce and Kevin Hoover (Pearce \& Hoover, 1995) for a discussion of the evolution of the ideas contained in Samuelson's textbook, Introductory Economics. The neo-classical synthesis first appeared in the third edition (Samuelson, 1955). I discuss the history of the development of New-Keynesian economics, and its roots in Samuelson's interpretation of Keynes, in my book, How the Economy Works, (Farmer R. E., 2010b).
} 
prices and the resulting theoretical construction makes Frankenstein's monster look like a beauty queen. ${ }^{8}$

But although the New-Keynesian reconciliation of Keynes with Walras is ugly, we should not infer that all possible reconciliations of Keynes with Walras will be similarly unattractive. NewKeynesian economics is built on two assumptions. The first is that aggregate quantities can be modeled 'as if' they were chosen by a single optimizing household with superhuman perceptions of future prices. The second is that an 'evil agent' throws sand into the adjustment process and prevents prices from quickly moving to equate the demands and supplies of all commodities.

I will argue here, that we can make considerable progress in our task of understanding the macroeconomy by relaxing each of these assumptions. I will take these two assumptions in turn. First, I will demonstrate that, by dropping the representative agent assumption, we may construct models with multiple equilibria that can be Pareto ranked. Second, I will explain a concept I call Keynesian search theory to provide a reconciliation of Keynes' concept of involuntary unemployment with Walrasian equilibrium theory that is different and more elegant than the sticky price explanation of New-Keynesian economics.

\section{Dropping the Representative Agent Assumption}

\section{Rational Expectations and Animal Spirits Can Coexist}

The representative household assumption is convenient because the mathematics of a model, populated by a representative household, is relatively simple. A single household facing a decision problem will always choose a unique action. But a household interacting with other households, most of whom have not yet been born, is a very different matter. Even if the physical world were unchanging, we would still face uncertainty as to the ways that our descendants will behave in the future. A model, populated by overlapping generations of finitely lived people, always has multiple equilibria. ${ }^{9}$

I will repeat that statement because it is so important and so misunderstood. A model, populated by overlapping generations of finitely lived people, always has multiple equilibria.

\footnotetext{
${ }^{8}$ Anyone who has ever tried to teach the New-Keynesian Phillips curve will grasp my meaning. The student is first introduced to the 'Calvo fairy', a mythical creature who randomly decides which firms, in any period, are allowed to contemplate changing prices. Next, one must assume that, in an inflationary environment, firms do not pick a price, they pick a mechanistic rule for adjusting their price on a weekly basis. The pricing rule must be aggregated over identical monopolistically competitive firms and the resulting equation must be linearized around a hypothetical stationary growth path. See my book, Prosperity for All (Farmer R. E., 2016) for a discussion of the connection between the ugly and unrealistic assumptions that under-pin the New-Keynesian model and the concentric circles used by Ptolemacian astronomers to justify their assumption that the Earth is at the center of the solar system. I first discussed the relationship between Ptolemacian astronomy and New-Keynesian economics in my paper (Farmer R. E., Animal Spirits, Persistent Unemployment and the Belief Function, 2012b).

${ }^{9}$ See my book, The Macroeconomics of Self-Fulfilling Prophecies (Farmer R. E., 1993), for a discussion of the role of multiple equilibria in macroeconomics.
} 
When we trade with other people in markets, we each make implicit assumptions about what we think will happen in the future. Our expectations of what will happen influence the way we behave. For much of the history of economics, that fact was taken as a given and economists built theories in which expectations, aka beliefs, were thought of as independent driving variables. But in 1972, all that changed. Robert Lucas wrote a paper (Lucas Jr., Expectations and the Neutrality of Money, 1972) in which he claimed that our beliefs about what will happen cannot independently influence what actually does happen.

Lucas's argument went something like this. Economists have dealt with uncertainty by tacking random variables onto otherwise deterministic models. That approach is inconsistent with the concept of rational behavior because the people who populate our models would surely come to recognize that the world is random.

Imagine a household decision maker who wanted to forecast some future price, $P$. Before Lucas, the economic theorist would hypothesize that the decision maker forms an expectation of $P$; call this expectation $P^{E}$. And because $P$ and $P^{E}$ are distinct variables, the theorist would need to add an equation to determine $P^{E}$. This equation often took the form of a so-called adaptive expectations equation.

Lucas argued that we should think of $P$ as a function of some underlying state of nature that we could denote by $S$. Think of $S$ as a die, cast by the gods. Economists refer to $S$ as fundamentals. The important assumption in Lucas' theory is the idea that every time nature throws a six, the price $P$, takes the same value, $P(6)$. More generally, we could denote the observed price with the notation $P(S)$, meaning that $P$ is a function of $S$. Importantly, if $S$ is always associated with $P(S)$ then it would be foolish to assume anything other than that $P^{E}(S)=P(S)$. In words, we do not need a separate equation to determine expectations. Drawing on a previous paper by John Muth (Muth, 1961), Lucas called this idea rational expectations (Lucas Jr., 1972).

In The General Theory (Keynes, 1936), expectations are drive by animal spirits which represent an independent driving force of business cycles. When Lucas introduced the concept of rational expectations into macroeconomics, he thought that he had banished the idea of animal spirits from macroeconomics. He was wrong.

Like a good magician who diverts your attention while withdrawing a card from his sleeve, Lucas slipped an assumption into his argument that almost nobody noticed. He assumed that there is a unique mapping from $S$ to $P$. While that may be true in the world of the representative household; it is never true in the world of overlapping generations. ${ }^{10}$ The implication of that fact is that we cannot dispense with an equation that selects the

\footnotetext{
${ }^{10}$ In a paper first released in 1984, (Farmer \& Woodford, 1997) Michael Woodford and I pointed out that the model used by Lucas to introduce rational expectations (Lucas Jr., 1972), contains an infinite dimensional continuum of equilibria. In my 1990 paper (Farmer R. E., 1990), I showed that the existence of multiple equilibria invalidates the universality of Lucas's celebrated critique of econometric modeling (Lucas Jr., 1976). In the first edition of my book, The Macroeconomics of Self-fulfilling Prophecies, (Farmer R. E., 1993), I proposed to resolve the indeterminacy of equilibria by introducing a new fundamental that I call a belief function.
} 
equilibrium. We must write down an equation that specifies how people think about the future; something similar to the adaptive expectations assumption. The dirty little secret here is that, when there are multiple equilibrium outcomes rational expectations and animal spirits can coexist.

\section{Equilibrium, Efficiency and the Great Lakes of North America}

I think it would be fair to say that Post Keynesians are not big fans of general equilibrium theory. Their antagonism to the equilibrium approach stems, I believe, not from the concept of equilibrium, but from the concept of efficiency. Under some very special circumstances, economic theorists have shown that every economic equilibrium is efficient in a well-defined sense: There is no intervention by a government agency that can improve the welfare of one person without making someone else worse off. That proposition goes by the imposing name of the first welfare theorem of economics and the efficiency concept, named after Vilfredo Pareto, (Pareto, 1906) is called Pareto Efficiency.

Let me stress something that is often overlooked, at least by macroeconomists. The first welfare theorem is just that, a theorem. There is a breed of macroeconomist whose natural habitat is the environs of the Great Lakes of North America, that views the first welfare theorem as a tautology. While the very best economists from the Great Lakes region are well aware of the qualifying conditions that are required for efficiency, that level of self-awareness is often lacking in their epigones.

The validity of the first welfare theorem rests on a set of assumptions about the structure of the economy. If these assumptions are a good characterization of the real world, we may infer that real world markets do a good job of allocating resources. If they are a poor characterization of the real world, the first welfare theorem is nothing but a beautiful mathematical abstraction.

If the assumptions of the first welfare theorem do not hold in the real world, we may still construct models in which aggregate quantities are modeled as markets in equilibrium; but we will not be entitled to infer that the allocations that arise from these markets are, in any way, optimal. To drive this point home; we might model an economy with twenty five percent unemployment as 'in equilibrium' without being forced to conclude that there is no possible government intervention that could improve peoples' lives. Although some equilibria may be Pareto Optimal, we need not conclude that all of them are.

This will not be surprising to most economists as economic theory has accepted the possibility of multiple equilibria, some of which may be Pareto inefficient, for a very long time. ${ }^{11}$ That was the main focus of my 1993 book, The Macroeconomics of Self-fulfilling Prophecies (Farmer R. E., 1993) and it is a theme that was well understood when I was an assistant professor at the

\footnotetext{
${ }^{11}$ A leading example that many will be familiar with is the concept of the prisoner's dilemma in game theory. It is rational for a prisoner to confess to a crime if he cannot guarantee that his partner will remain silent.
} 
University of Pennsylvania in the 1980s. ${ }^{12}$ But the obsession of macroeconomists with the representative household assumption has blinded them to the possibility that equilibrium outcomes may be very far from optimal. Let me expand on that idea, by relating it to a popular idea in the finance literature; the concept of efficient markets.

\section{Post Keynesians, New Keynesians and the Grim Reaper}

The efficient markets hypothesis is a term coined by Eugene Fama to denote the idea that it is difficult or impossible to make money through trades in the financial markets unless you know something that somebody else does not know. Fama refers to that idea as informational efficiency and there is a large finance literature which argues, persuasively, that markets are efficient in this sense (Fama, 1970). It is unfortunate that Fama used the term efficiency to describe this concept because it has nothing to do with the way that economists typically use that term. A market that is informationally efficient is not necessarily Pareto efficient.

What does this mean and why is it important? Let us conduct an imagined dialogue between a North American economist from the Great Lakes region, I will call her Janet, and a Post Keynesian graduate student who has read my book, Prosperity for All (Farmer R. E., 2016). I will call him Brad.

Janet: The distinction between informational efficiency and Pareto efficiency is a distraction. If people trading in the financial markets cannot make money, nor can the government. There is no such thing as a free lunch.

Brad: I disagree. The fact that a market is in equilibrium does not mean that it is efficient.

Janet: Well OK, I know that you Post-Keynesian types are willing to make all sorts of assumptions about market frictions. Those assumptions don't seem credible to me. As a first approximation, I am willing to assume that prices are perfectly flexible.

Brad: You seem to be confusing me with a New-Keynesian. I'm happy with the flexible price assumption. I'll give you that one.

Janet: Well perhaps you think that there are missing financial markets. I know that Kenneth Arrow has argued that transactions costs preclude the existence of all the financial instruments necessary to generate market efficiency (Arrow, 1964). But I don't buy that. If there are big potential gains from trade, there are big incentives for private agents to create new markets. Just look at all the derivatives that were created over the last few decades. They came about because of lower transactions costs. I'm willing to assume, to a first approximation, that there is a complete set of financial markets.

\footnotetext{
${ }^{12}$ For a discussion of the evolution of the research agenda on endogenous business cycles, sunspots and multiple equilibria, see my survey paper, The Evolution of Endogenous Business Cycles (Farmer R. E., 2014).
} 
Brad: While that seems like a stretch; I'll give you that one too. Let's assume that there is a complete set of financial markets and that everyone participating in the financial markets can make any conceivable trade in the futures markets at zero cost.

Janet: Is it the assumption of perfect knowledge you're uncomfortable with? I know that Frank Knight (Knight, 1933) drew a distinction between risk and uncertainty and that you Post Keynesian types keep harping on about radical uncertainty. Although you may have a point there, I just don't see how we can make any progress if we assume that nobody knows anything about the future. I'm willing to go with the assumption that we live in a stationary world because it's the best chance we have of saying something about the behavior of short-run macroeconomic variables. And that means that we should also assume that people have rational expectations.

Brad: Well I'm not entirely on board with that. But, for the sake of argument, let's agree to model the way that human beings would act if they did live in a world where all uncertainty is generated by a known stationary probability distribution and where the people in our model have rational expectations. If we can agree on the answer to what an equilibrium would look like in that world, then perhaps we can extend our equilibrium concept to a more complicated world where the future is characterized by radical uncertainty.

Janet: Hmmm... If you accept all of these assumptions, I'm having trouble understanding why you don't understand that, if private agents can't make money in markets, then neither can the government. Maybe you're one of those Marxist types who thinks that product markets are characterized by monopolists and we need unions to defend workers' rights. In my view, that's a load of poppycock. Product markets are contestable and, to the extent they're not, the solution is limited regulation. I don't see what that has to do with the distinction between informational efficiency and Pareto efficiency.

Brad: Wow: you really have drunk the Kool-Aid. But no; that's not my point either. Let's suppose you're right that the labor market and the product markets are well approximated by the assumption of perfect competition. I'm willing to give you flexible prices, complete markets, rational expectations, and perfect competition. But there's one little fact you can't get around.

Janet: What's that Brad?

Brad: The Grim Reaper. People die and new people are born. Even if everyone present today could make trades with each other contingent on every conceivable future event, the unborn cannot participate in markets that open before they are born. Government, on the other hand, is present in every period and it can intervene on behalf of our children and our grandchildren.

Janet: Nonsense. We don't need government for that; we need the family. Robert Barro showed that all we need to correct the inefficiency in an overlapping generations 
model is for parents to love their children. The representative household is a useful fiction because each of us is connected by a chain of operative bequests. ${ }^{13}$

Brad: You're wrong Janet. Overlapping generations models have not one, but two kinds of inefficiencies. Robert Barro's argument applies to dynamic inefficiency, which is the fact that, in overlapping generations models, interest rates can be too low. There is a second kind of inefficiency that was pointed out by David Cass and Karl Shell (Cass \& Shell, 1983). And Costas Azariadis (Azariadis, 1981) showed that overlapping generations models can lead to volatile fluctuations in asset markets that have nothing to do with fundamentals. In his book, Prosperity for All (Farmer R. E., 2016), Farmer argues that a large fraction of the fluctuations we see in stock markets are caused by this second kind of inefficiency. And this second kind of inefficiency cannot be eliminated by the family because it would require that our parents leave positive bequests in some states of nature and negative bequests in other states of nature.

My imagined conversation between Janet and Brad is meant to illustrate the idea that we can accept the tenets of temporary equilibrium theory while rejecting the first welfare theorem. The conversation focuses on why government might have an advantage over private markets and it focuses on one specific market failure; the inability of human beings to participate in insurance markets that open before they are born.

In my published academic books and papers, I accept the obviously false assumption that uncertainty is well characterized by a known time invariant probability distribution. I am happy to make this assumption because I want to distinguish features of the real world that arise because nature rolls a loaded and time varying die, from features of the real world that arise from the way human beings react to this fact.

Imagine a human being whose sole purpose in life is to play a repeated game against nature. Each time the game is repeated, the probability of any given outcome is the same. In that environment, it is reasonable to suppose that eventually the human being would learn the probability of any particular move by nature. For example, the probability of snow in Minneapolis in December is close to 1. Given that fact, the human being playing the game will choose to purchase warm clothing.

Contrast that situation with a human being who plays a game against other human beings. Each time the game is repeated, some of the players are replaced by new ones. Suppose further, that every player seeks to achieve a well-defined goal and assumes correctly, that every other player has the same objective. An equilibrium, in game theory, is a strategy for each player that cannot be improved upon, given the strategies played by the other players. I contend that we can understand a great deal about real world economies by modeling them as a repeated game between a changing set of players and it is a fact that many games of this kind have more than one equilibrium. A temporary equilibrium, in the sense of Hicks, is a special case of such a game

\footnotetext{
${ }^{13}$ Barro's work on this topic is contained in his paper, 'Are Government Bonds Net Wealth? (Barro, 1974).
} 
and my statement that overlapping generations models possess multiple equilibria is a recognition of that fact.

As Hicks conceived it, temporary equilibrium theory does not require that people have rational expectations. Post Keynesians have been vehement critics of the rational expectations hypothesis but I am inclined to accept it as a working assumption in order to focus on a more important issue; the existence of persistent high unemployment as a possible equilibrium outcome.

While I have considerable sympathy for the notion of radical uncertainty, like Brad in my dialogue, I think it is fruitful to ask how a society of interacting human beings would act in a world in which all uncertainty was generated by a sequence of known stationary probability measures. In other words, let us suspend disbelief and accept the assumption that the future is characterized by what Frank Knight called risk as opposed to uncertainty.

\section{Dropping the Sticky Price Assumption}

\section{Unemployment and Keynesian Search Theory}

That leads me to a more contentious point of disagreement between New-Keynesian and Post Keynesian economists: How should we think about unemployment? In the 1970s, conventional economists gave up on Keynes and accepted the Lucasian argument for a return to classical principles. One reason for this apostasy is that Keynes did not provide a satisfactory answer to the question: Why don't firms offer lower wages to unemployed workers?

Microeconomists of the post WWII period wanted to understand macroeconomics in terms of microeconomic principles and neither Keynes himself, nor the North American Keynesians at Harvard, Yale and MIT provided a satisfactory answer. ${ }^{14}$ Their attempts led to the split between Post Keynesians, who carried the torch of Keynesian purity, and New Keynesians, who provided a highly unsatisfactory answer to the unemployment question; unemployment persists because wages and prices are sticky. Post Keynesians have correctly pointed out that Keynes denied that his theory was grounded on the assumption of sticky wages and prices. ${ }^{15}$ But as Don Patinkin once said to me; if The General Theory was not about sticky prices, what was it about? ${ }^{16}$

I have an answer to that question. The labor market is not an auction in which a fictitious character asks buyers and sellers to submit demands and supplies until he has found a set of

\footnotetext{
${ }^{14}$ Leading North American Keynesians included Alvin Hansen at Harvard, Robert Solow, Paul Samuelson and Franco Modigliani at M.I.T. and James Tobin at Yale.

${ }^{15}$ This has also long been a theme of my own interpretations of Keynesian economics. See, for example, my paper Sticky Prices (Farmer R. E., 1991).

${ }^{16}$ I was privileged to take a class from Don Patinkin on the history of thought when I was a graduate student at the University of Western Ontario. Later, I got to know him well as a colleague when he visited UCLA often to teach for one quarter a year. During our conversations he displayed a considerable skepticism for the notion that The General Theory is about sticky wages or sticky prices, an irony that was not lost on him since Don's own work had been instrumental in the development of that interpretation of Keynes' General Theory.
} 
market-clearing prices. It is a search market in which buyers and sellers are randomly matched. I am going to borrow a concept from a recent literature that I call classical search theory in which we conceive of a matching function that determines the probability of a meeting between a buyer and a seller. A neoclassical production function describes the different ways in which commodities can be produced from labor and capital. Similarly, a matching function describes the ways in which a filled job can be produced from given numbers of searching unemployed workers and searching members of the recruiting departments of firms.

One hundred bushels of corn per week can be harvested by ten people with scythes or by one person with a combine harvester. Similarly, one hundred jobs per week can be filled if five hundred people search for two hundred vacancies or if two hundred people search for five hundred vacancies.

When prices are set in auction markets, the relative prices of labor and capital send signals to farmers that cause them to choose the best combination of labor and capital. Best, does not just mean that the farmer makes as much profit as possible. It also means that labor and capital are efficiently allocated from a social perspective. This important insight, captured by the first welfare theorem of economics, explains why capitalist market economies triumphed over soviet social planning. Under some circumstances; markets work well.

But although capitalist market economies are a great deal better at allocating resources than soviet social planning; they are not perfect. Sometimes, markets go very badly wrong. Nobody would argue that twenty-five percent unemployment in the United States during the Great Depression was evidence of the success of markets. As Modigliani famously quipped, the Great Depression was not caused by a sudden attack of contagious laziness (Modigliani, 1977).

Even if markets worked efficiently, we would not expect unemployment to be driven to zero. The labor market is dynamic and people continuously leave old jobs and look for new ones. It takes resources to quickly match labor market entrants with the right job. Firms must divert people from the activity of producing commodities to the activity of screening new job applicants. To reduce the unemployment rate to zero, firms would need to divert so many people to the personnel department that production would suffer.

I will refer to the unemployment rate that maximizes social output of commodities as the natural rate of unemployment. A successful theory of Keynesian unemployment must explain how equilibrium unemployment can differ from the natural rate of unemployment. NewKeynesians explain this divergence by invoking the assumption of sticky prices. In contrast, to the New-Keynesians, my work demonstrates that unemployment persists because the labor market is incomplete. Labor market equilibrium is Pareto inefficient because there are not enough relative prices to allocate resources between competing ends.

In my book, Prosperity for All (Farmer R. E., 2016), I propose a new branch of search theory that I call Keynesian search theory. I distinguish it from classical search theory which refers to the work of Peter Diamond, Dale Mortensen and Christopher Pissarides and for which they were 
awarded the Nobel Prize in 2010. ${ }^{17}$ In classical search theory, the absence of prices to determine the allocation of job search between unemployment and vacancies, is replaced by the assumption that workers and firms bargain over wages.

Keynesian search theory departs from classical search theory in a fundamental way. In classical search theory the multiplicity of equilibrium is resolved by introducing a new parameter, the worker's bargaining weight. In Keynesian search theory the multiplicity is resolved, instead, by assuming that beliefs about the future value of the stock market is a new fundamental. The allocation of job search between unemployment and vacancies is pinned down by aggregate demand and aggregate demand is, in turn, determined by the animal spirits of participants in the asset markets. ${ }^{18}$

\section{Everything You Need to Know About Macroeconomics}

I have made two arguments in this paper. First, the capital markets are inefficient because not all people are able to participate in them. I have shown in my published research that that fact implies that the wealth of market participants may move up and down in arbitrary ways driven purely by beliefs. ${ }^{19}$ Animal spirits are fundamentals that should be granted the same methodological status as technologies, preferences and endowments.

Second, the labor market is a not an auction; it is a Keynesian search market in which the unemployment rate is determined by aggregate demand. That fact leads to an equilibrium concept in which any unemployment rate can be an equilibrium. ${ }^{20}$ In contrast to the ideas that were developed by the New Keynesians, the equilibria in my models are stationary and can potentially persist forever.

These two arguments can be related to a diagram that, in times gone by, was taught to every student of macroeconomics: The Keynesian Cross, a formulation of the central ideas in The General Theory, appeared as a central component of macroeconomic theory as it was taught by Samuelson in his textbook, Economics: An Introductory Analysis (Samuelson, 1955). The Keynesian Cross plots income on the horizontal axis and expenditure on the vertical axis.

\footnotetext{
${ }^{17}$ In Prosperity for All, I first used the term Keynesian search theory to distinguish my work, where equilibrium selection occurs in the asset markets, from the works by Peter Diamond (1982), Dale Mortensen, (1970) and Christopher Pissarides (1976) (DMP) where equilibrium selection occurs in the labor. I refer to the DMP model as classical search theory.

${ }^{18}$ I first developed these arguments in a paper (Farmer R. E., Old Keynesian Economics, 2008) that was presented at a 2006 conference in honor of Axel Leijonhufvud. It is further explored in two papers, (Farmer R. E., Confidence, Crashes and Animal Spirits, 2012a) and (Farmer R. E., Animal Spirits, Financial Crises and Persistent Unemployment, 2013). The ideas are also presented in three books, (Farmer R. E., Expectations, Employment and Prices, 2010a), (Farmer R. E., How the Economy Works: Confidence, Crashes and Self-fulfilling Prophecies, 2010b) and (Farmer R. E., Prosperity for All: How to Prevent Financial Crises, 2016).

19 (Farmer R. E., Expectations, Employment and Prices, 2010a)

${ }^{20}$ (Farmer R. E., Confidence, Crashes and Animal Spirits, 2012a).
} 


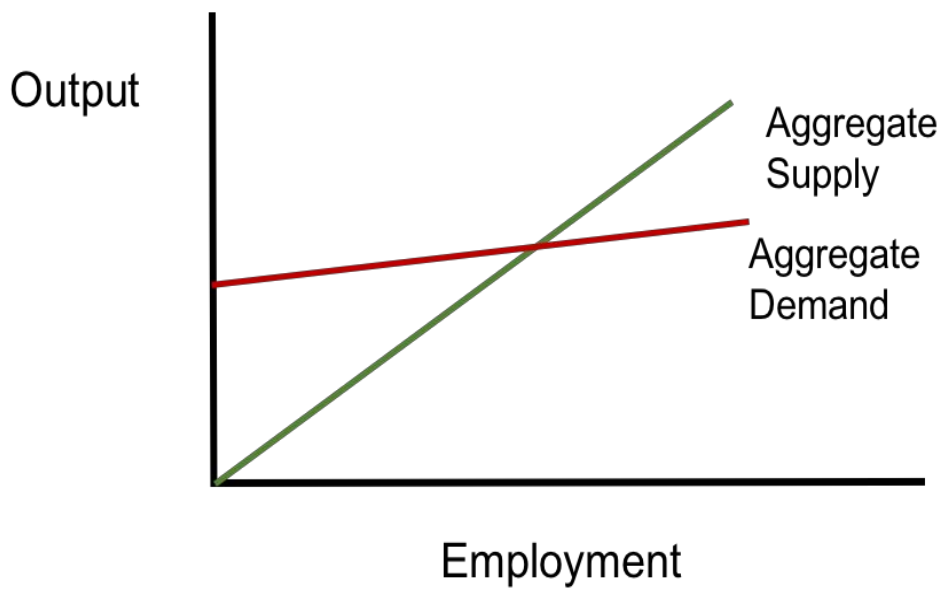

\section{Figure 1: The Keynesian Cross}

In Figure 1, I have graphed a version of the Keynesian Cross that is closer in spirit to the General Theory than the version developed by Samuelson. In contrast to Samuelson's version, my version plots employment on the horizontal axis and output, measured relative to the money wage, on the vertical axis. ${ }^{21}$ The student who truly understands this diagram is well on the way to mastering the most important ideas in macroeconomics. It illustrates the two most important concepts in The General Theory, concepts that have formed the basis for everything I have drawn attention to in my work.

The first is the idea of beliefs as an independent driver of business cycles. According to Keynes, animal spirits, aka beliefs, is an independent driving variable that shifts the aggregate demand curve up and down. As the curve shifts, so its intersection with aggregate supply also shifts. This intersection represents an equilibrium, or rest point, of the macroeconomy. An important research question for macroeconomics is: what are the determinants of the aggregate demand curve and why does it shift around in sometimes unpredictable ways over time? In my view, Keynes' theory of the consumption function is inadequate to answer this question. We should instead explicitly model the connections between consumption and wealth.

The second is the idea that any unemployment rate can persist as a steady state equilibrium. Keynes argued, correctly in my view, that unemployment is often involuntary. But he did not provide an adequate explanation of aggregate supply and, notably, he did not explain to the satisfaction of his contemporaries how high involuntary unemployment can persist in equilibrium. My work on Keynesian search theory provides that explanation. Unemployment

\footnotetext{
${ }^{21}$ Following Keynes, I am measuring employment in units of ordinary labor and I am measuring output in wage units. I explain this diagram in my published paper Aggregate Demand and Supply (Farmer R. E., Aggregate Demand and Supply, 2008). The use of employment and output on the axes reflects the definitions in Chapter 4 of The General Theory (Keynes, 1936). In his exposition of Keynesian Economics, Samuelson amended this diagram by plotting income on the horizontal axis and expenditure on the vertical axis.
} 
persists because the labor market is a search market, not an auction market, and there are insufficiently many relative prices to coordinate the behaviors of market participants.

Post Keynesian finches and their New Keynesian cousins have avoided each other for far too long. Just as the arrival of El Niño in the Galapagos Islands allowed diverging species to once more merge, it is my hope that the shock of the Great Recession will catalyze interbreeding between new-Keynesian and heterodox economists. If I am right, more of my neo-classical contemporaries will need to listen to the drum beat that post-Keynesians have been sounding for sixty years. And Post-Keynesians will need to explain to neo-classical and new-Keynesian economists, in their own language, what they are doing wrong. General equilibrium theory, broadly interpreted, like mathematics, is a language. If you are young enough to have not yet been corrupted by establishment elites of either subspecies, I urge you to think hard about joining me in establishing Post-Keynesian DSGE theory as the future of macroeconomics.

\section{References}

Arrow, K. J. (1964). The Role of Securities in the Optimal Allocation of Risk Bearing. Review of Economic Studies, 31(2), 91-96.

Azariadis, C. (1981). Self-fulfilling Prophecies. Journal of Economic Theory, 25(3), 380-396.

Barro, R. J. (1974). Are Government Bonds Net Wealth? Journal of Political Economy, 82(6), 1095-1117.

Barro, R. J., \& Grossman, H. (1971). A General Disequilibrium Model of Income and Employment. American Economic Review, 61, 82-93.

Benassy, J. P. (1975). Neo-Keynesian Disequilibrium in a Monetary Economy. Review of Economic Studies, XLII (4)(132), 503--524.

Cass, D., \& Shell, K. (1983). Do Sunspots Matter? Journal of Political Economy, 91, 193-227.

Clower, R. (1967). A Reconsideration of the Microfoundations of Monetary Theory. Western Economic Journal, 6(1), 1--8.

De Vroey, M. (2006). The Temporary Equilibrium Method: Hicks Against Hicks. European Journal of the History of Economic Thought, 13(2), 259--278.

Diamond, P. A. (1982). Wage determination and efficiency in search equilibrium. Review of Economic Studies, 49, 217-227.

Fama, E. F. (1970). Efficient Capital Markets: A Review of Theory and Empirical Work. Journal of Finance, 25(2), 383-417.

Farmer, R. E. (1990). The Lucas Critique, Policy Invariance and Multiple Equilibria. Review of Economic Studies, 105(1), 43-60.

Farmer, R. E. (1991). Sticky Prices. Economic Journal,, 101(409), 1369-1379. 
Farmer, R. E. (1993). The Macroeconomics of Self-Fulfilling Prophecies. Cambridge, MA: MIT Press.

Farmer, R. E. (2008, March). Aggregate Demand and Supply. International Journal of Economic Theory, 4(1), 77-94.

Farmer, R. E. (2008). Old Keynesian Economics. In R. E. Farmer (Ed.), Macroeconomics in the Small and the Large (pp. 23-43). Cheltenham, UK: Edward Elgar.

Farmer, R. E. (2010a, March). Expectations, Employment and Prices. New York: Oxford University Press.

Farmer, R. E. (2010b, April). How the Economy Works: Confidence, Crashes and Self-fulfilling Prophecies. New York: Oxford University Press.

Farmer, R. E. (2012a, March). Confidence, Crashes and Animal Spirits. Economic Journal, 122(559).

Farmer, R. E. (2012b). Animal Spirits, Persistent Unemployment and the Belief Function. In R. Frydman, \& E. S. Phelps (Eds.), Rethinking Expectations: The Way Forward for Macroeconomics (pp. 251-276). Princeton, NJ: Princeton University Press.

Farmer, R. E. (2013). Animal Spirits, Financial Crises and Persistent Unemployment. Economic Journal, 123(568), 317-340.

Farmer, R. E. (2014). The Evolution of Endogenous Business Cycles. Macroeconomic Dynamics.

Farmer, R. E. (2016). Prosperity for All: How to Prevent Financial Crises. New York: Oxford Univesity Press.

Farmer, R. E., \& Woodford, M. (1997). Self-fulfilling Prophecies and the Business Cycle. Macroeconomic Dynamics, 1(4), 740-769.

Hicks, J. R. (1939). Value and Capital (2nd Edition, 1946 ed.). Oxford: The Clarendon Press.

Hume, D. (1777). Of Money. In Essays, Moral, Political and Literary, based on the 1777 edition originally published as vol 1. of Essays and treatisies on several subjects. Indianapolis: Liberty Fund.

Keynes, J. M. (1936). The General Theory of Employment, Interest and Money. London and Basingstoke: MacMillan and Co.

Knight, F. H. (1933). Risk Uncertainty and Profit. New York: Augustus M Kelly.

Leijonhufvud, A. (1966). On Keynesian Economics and the Economics of Keynes. Oxford University Press.

Lucas Jr., R. E. (1972). Expectations and the Neutrality of Money. Journal of Economic Theory, 4, 103-124. 
Lucas Jr., R. E. (1976). Econometric Policy Evaluation: A Critique. In K. Brunner, \& A. H. Meltzer (Ed.), Carnegie Rochester Conference Series on Public Policy (pp. 104-130). NorthHolland.

Malinvaud, E. (1977). The theory of unemployment reconsidered. Oxford: Basil Blackwell.

Minsky, H. P. (2008). Stabilizing an Unstable Economy (Second ed.). McGraw Hill.

Modigliani, F. (1977). The Monetarist Controversy or, Should We Forsake Stabilization Policies? American Economic Review, 67(March), 1-19.

Mortensen, D. T. (1970). A Theory of Wage and Employment Dynamics. In E. S. Phelps, G. C. Archibald, \& A. A. Alchian (Eds.), Microeconomic Foundations of Employment and Inflation Theory. New York: W. W. Norton.

Muth, J. F. (1961). Rational Expectations and the Theory of Price Movements. Econometrica, 29(3), 315-335.

Pareto, V. (1906). Manual of Political Economy. London: Macmillan, English Edition, 1972.

Patinkin, D. (1956). Money Interest and Prices (Second abridged ed.). Cambridge, Massachusetts: The MIT Press.

Pearce, K. A., \& Hoover, K. D. (1995). After the Revolution: Paul Samuelson and the Textbook Keynesian Model. History of Political Economy, 27(Supplement), 183--216.

Pissarides, C. A. (1976). Job Search and Participation. Economica, 43, 333-349.

Samuelson, P. A. (1955). Economics: An Introductory Analysis (3rd Ed.). McGraw Hill.

Walras, L. (1899). Elements of Pure Economics, 4th ed. 1926, rev ed. 1926, Engl transl. 2003. New York: Routledge.

Weiner, J. (1995). The Beak of the Finch. New York: VIntage Book; Random House.

Woodford, M. (2003). Interest and Prices: Foundations of a Theory of Monetary Policy. Princeton, N.J.: Princeton University Press. 